\title{
Materials From Hazardous Iron Ore Treatment Waste, Concrete Demolition Debris And Lime Production Waste to Increase Environmental Sustainability of Industrial Regions
}

\author{
Vsevolod Mymrin ( $\square$ seva6219@gmail.com ) \\ Universidade Tecnologica Federal do Parana - Campus Medianeira \\ Ana Povaluk \\ Universidade Tecnologica Federal do Parana - Campus Medianeira \\ Luana Cechin \\ Universidade Tecnologica Federal do Parana - Campus Medianeira \\ Monica A. Avanci \\ Universidade Tecnologica Federal do Parana - Campus Medianeira \\ Cleber L. Pedroso \\ Universidade Tecnologica Federal do Parana - Campus Medianeira \\ Daniela E. Pedroso \\ Universidade Tecnologica Federal do Parana - Campus Medianeira \\ Paulo H.B. Rolim \\ Universidade Tecnologica Federal do Parana - Campus Medianeira \\ Karina Q. Carvalho \\ Universidade Tecnologica Federal do Parana - Campus Medianeira
}

\section{Research Article}

Keywords: Hazardous iron ore treatment waste, Concrete production and demolition debris, Lime production waste, Structure formation processes, Environmentally sustainable materials

Posted Date: November 11th, 2021

DOI: https://doi.org/10.21203/rs.3.rs-1041333/v1

License: (1) This work is licensed under a Creative Commons Attribution 4.0 International License.

Read Full License 


\section{Abstract}

To prevent environment pollution by hazardous industrial dumps of iron ore treatment sludge, concrete production/demolition debris and lime production waste sustainable cement-less construction materials were developed for substitution of traditional natural raw components excavated in careers, irreversibly destroying natural bonds. Their axial resistance values on the $3^{\text {rd }}$ day of hydration were till $2.34 \mathrm{MPa}$, on the $28^{\text {th }}$ day - up to $3.94 \mathrm{MPa}$, on the $180^{\text {th }}$ day $8.40 \mathrm{MPa}$ and on the $365^{\text {th }}$ day $10.22 \mathrm{MPa}$. The expanding coefficient on the $3^{\text {rd }}$ day were till $2.13 \%, 2.51 \%$ on the $28^{\text {th }}$ day, and on the $365^{\text {th }}$ day $2.22 \%$. Water absorption on the $28^{\text {th }}$ day was $7.17-9.32 \%$ and decreases to $6.26-8.64 \%$ on the $90^{\text {th }}$ day. All these characteristics correspond to the Brazilian norms. The physical - chemical processes of materials' structures formation included alkaline dissociation of solid particles' surface, with sol appearing and densification till transition to gel. Long-lasting gel compaction and densification to stone-like condition made its structure similar to natural rock materials - silica, opal, obsidian, perlite, pumice, amber, flask, etc. They can be used for production of road bases, concrete blocks and solid unburned bricks, among other sustainable construction materials.

\section{Highlights}

- New material from iron ore tailing, concrete and lime production wastes

- Axial resistance reached 1.68 MPa on $3^{\text {rd }}$ day and $10.22 \mathrm{MPa}$ on the $365^{\text {th }}$ day

- By methods of XRD, SEM and EDS were founded the processes of the materials hardening

- Utilization of industrial wastes has high environment and economic efficiency

\section{Introduction}

Industrial and municipal waste in solid, liquid and gaseous forms are the main environmental pollutants of our planet. The constant rise in atmospheric temperature caused by them calls into question the survival ability of future generations of people. According to the authors of this study, the only way to overcome this dangerous trend is to develop methods for the disposal of all types of waste as valuable raw materials and to apply them at an industrial level with a remarkably high environmental and economic efficiency.

The results of this experimental study convincingly prove the possibility of environmentally friendly building materials' producing from such most widely spread industrial waste as iron ore treatment waste (IOT), concrete production and demolition debris (CDD) and lime production wastes (LPW) instead of more costly traditional natural components of building materials - sand, clay, crushed stone, rock gravel and others.

For the Institute of Technological Research (IPT) of Brazil, the world reserve of iron in 2016 was near 170 billion tons; during production of one ton of iron is generated near $400 \mathrm{~kg}$ of IOT sludge (i.e., annually 
about 289 million tons of IOT sludge) with exceptionally low level (5.4\%) of utilization (IPT, 2019). The calculations of Freitas, et al (2019) demonstrated even worse results - only $0.003 \%$ IOT are reused. Therefore, between the years 2000 and 2017 there were 36 cases of IOT tailings dams' failures in the world, an average of two per year, which caused significant environmental damage (Wise Uranium (2015). Two major irreparable disasters occurred in 2015 in Brazil (Mariana), in which 50 million cubic meters of IOT leaked and reached the Atlantic Ocean; the second one was in Brumadinho (2020) that poured 13 million cubic meters (Freitas, et al, 2019). One of the best ways to avoid similar harmful damages is to apply IOT as a principal valuable by-product for civil construction material and to decrease its accumulation in the dumps. Galvão et al (2018) offering it as a sustainable reddish paint for construction pigment; for mortars and laying bricks production (Fontes. et al, 2016); for Portland cement clinker (Luo, et al, 2016; Yao, et al, 2020); to improve resistance to sulfates attacks (Xiong, et al, 2017); as replacement for fine aggregate in concrete (Shettima, et al, 2016).

Concrete production and demolition (CDD) debris is a waste of all types of technological processes associated with the production and destruction of building concrete. The amount of its production in different countries is estimated differently and depends mainly on the life standard of the society. For example, in the European Union (2018) it reached $46 \%$ in 2018 of the total amount of waste (Akhtar and Sarmah, 2018) and much less in developing countries (Huanga, et al, 2018). Zhang, et al (2017) informed that annual CDD production in China is about 3 billion tons. Typical components in the CW are inert materials, such as concretes with almost $90 \%$ of natural rocks, mortars, and ceramics, slate, glass, which have proven to be a substitute for natural aggregates (Fatemi and Imaninasab, 2016). According to Brazilian norm NBR 15116 (2004), at least 90\% of CDD mass are fragments of natural rocks.

Therefore, Silva, de Brito and Dhir (2014) studied properties and composition of recycled aggregates from construction and demolition waste suitable for concrete production. Xuan, Sun and Zheng (2018) applied CDD non-structural concrete artifacts and for cement production (Robalo, et al, (2021); in composites with fly ash, dust from cement kilns and gray water (Bassani, 2019).

Large amount of lime production waste (LPW) is formed mainly due to two reasons: when calcining carbonate rocks occurred below $960^{\circ} \mathrm{C}$ or during long-term storage of lime with access of humid air. Brazilian norms NBR 6453 (2003) allow a maximum of $12 \%$ of total $\mathrm{CO}_{2}$ content with chemical impurities like $\mathrm{Fe}_{2} \mathrm{O}_{3}, \mathrm{Al}_{2} \mathrm{O}_{3}, \mathrm{SiO}_{2}$. Otherwise, this material is called lime production waste (LPW) and cannot be marketed and used as construction lime.

Usually, LPW is used for sanitary purposes of municipal sewage sludge treatment, to create an alkaline environment for various technological processes, like activator of chemical slag-soil interaction of road base construction in Kazakhstan (Mymrin, et al, 2019). Pedroso (2019) cement-less concrete from three types of industrial wastes: of cellulose production, concrete demolition (CDD) and lime production. LPW can be used in composites with two different types of spent sunflower cooking oils and brick waste powder as pozzolanic addition of new lime mortars (Pahlavan, et al, 2017) or glass mortars (Yang, Poon, Ling, 2019); to produce cementless controlled low-strength material based on waste glass powder (Xiao, 
et al, 2021); for soil stabilization based on recycled-glass powder waste and dolomitic lime (Baldovino, et al, 2021); for preparation of geopolymer (El-Naggar, et al, 2019); as amendment of municipal sewage sludge with lime and mussel shell (Wang, et al, 2019) or for production of lime-incineration sewage sludge ash pastes (Zhou, et al, 2021); for cementless controlled low-strength material based on waste glass powder (Xiao, et al, 2021). LPW was used also Karanac, et al (2018) fly ash as a low-cost adsorbent of $\mathrm{Zn}^{2+}, \mathrm{Pb}^{2+}$, and $\mathrm{As}^{+5}$ ions.

\section{Objectives of the study}

A study of the available world scientific research literature, some of them are mentioned above, showed that there is no information on the development of building materials, produced from iron ore treatment waste, concrete production / demolition debris and lime production waste. The production of building materials is the largest consumer of natural resources, a significant part of which can be replaced by industrial and municipal waste with remarkably high environmental and economic efficiency. The recent ecological disasters in brazilian history forced the development of as many compositions of building materials as possible with the largest content of these and other waste. The solution to this problem is the main goal of this study. Elucidation of the physicochemical processes of the developed building materials' structure formation was an equally important goal since their structures explain all the properties and reliability of materials during their operation.

\section{Materials And Methods}

\subsection{Raw materials and Test Samples (TSs) preparation}

Two raw materials under study - concrete waste (CW) and lime production waste (LPW) were collected from the dumps of in the metropolitan region of Curitiba, Brazil enterprises. The iron ore waste (IOW) was collected after the Fundão burst in 2015 in Mariana, Minas Gerais, Brazil.

The dry mix of components was manually homogenized, hydrated to $15-17 \%$, sealed in a manual Bovenau hydraulic press, in a cylindrical format with a height and diameter of $20 \mathrm{~mm}$ at a force of $5 \mathrm{MPa}$ for 30 seconds, and stored in outdoor condition for various test periods; 60 TSs were made for each of the 16 compositions with total quantity near 1,000 samples. The TSs' properties were carried out by averaging five measurements with the calculation of standard deviation values.

\subsection{Methods}

To investigate mechanical and physical properties the following tests were carried out: resistance to axial compression, water resistance, water absorption, expansion and shrinkage. The leaching and solubility tests were carried out for IOT sludge as the most polluted raw component and for composition 12 with the biggest (60\%) IOT content on the 90th curing day. To study the raw materials and the developed composites' physicochemical processes of structure's formation, the following methods were applied: the particle size distribution was performed by a Bettersizer S3 Plus laser diffraction analyzer, in combination 
with sew method; chemical composition of the raw materials by X-ray fluorescence analysis (XRF); mineral composition by X-ray diffraction (XRD) with automated database of minerals PDF-2; the chemical composition of new formations - by the method of energy-spectrum spectroscopy (EDS) and isotope composition by laser micro-mass analysis (LAMMA); morphological structure of the samples - by scanning electron microscopy (SEM); solubility and leaching of metals - by atomic absorption analysis (AAA).

\subsection{Calculations}

The water resistance coefficient $\left(\mathrm{C}_{\mathrm{WR}}\right)$ was determined based on the ratio:

$C_{W R}=R_{S A T} / R_{D}(E q .1)$

where $R_{S A T}$ is the axial compressive strength of saturated TSs after total immersion in water for

24 hours; and $R_{D}$ is the axial compressive strength of the specimen oven-dried at $100^{\circ} \mathrm{C}$ for 24 hours.

Water absorption values were calculated in accordance with the equation:

$W A=[(M h-M d) / M d] \cdot 100(E q .2)$

Where, WA - the absorption of water by the test sample (\%),

Ms - mass of the sample after drying in oven at a temperature of $110^{\circ} \mathrm{C}$ for 24 hours $(\mathrm{g})$

Mh - mass of the humid test sample after immersion in water at room temperature for 24 hours $(\mathrm{g})$

\section{Research's Results}

The research's results are presented in the following three sections:

3.1. Characterization of the initial components;

3.2. Mechanical and physical properties of the developed materials;

3.3. Physicochemical processes of its structure's formation explaining the reasons of these properties obtaining.

\subsection{Raw materials characterization}

All raw materials were characterized on particle size distribution, chemical and mineral compositions and structures' micro morphology.

\subsubsection{Particles' sizes distribution of the raw materials}


Comparison of the particles' sizes distribution of the raw materials (Table 1) demonstrates that the particles thicker than $9.50 \mathrm{~mm}$ are in CDD (8.53 \%) with total amount of particles between 2.00- and 9.50$\mathrm{mm}$ sizes $84.75 \%$, followed by IOT (75.50\%). IOT contains slightly larger particles having less than 2.00 $\mathrm{mm}-18.0 \%$ than RC $-12.1 \%$.

Table 1

- Particles' sizes distribution of the raw materials

\begin{tabular}{|lllll|}
\hline $\begin{array}{l}\text { Sieve } \\
(\mathbf{m m})\end{array}$ & $\begin{array}{l}\text { IOT, } \\
\text { wt. } \%\end{array}$ & $\begin{array}{l}\text { CDD, } \% \\
\text { wt. }\end{array}$ & $\begin{array}{l}\text { Laser analyzer } \\
(\mathbf{m m})\end{array}$ & $\begin{array}{l}\text { LPW, } \\
\text { wt. } \%\end{array}$ \\
\hline 9.50 & 0 & 8.53 & 2.0 & 0.36 \\
\hline 4.76 & 0.57 & 4.44 & 0.5 & 0.20 \\
\hline 4.00 & 0.32 & 3.11 & 0.25 & 2.60 \\
\hline 2.36 & 5.10 & 8.34 & 0.063 & 0.14 \\
\hline 2.38 & 25.33 & 45.86 & 0.036 & 5.33 \\
\hline 2.00 & 37.90 & 10.28 & 0.028 & 8.04 \\
\hline 1.68 & 16.18 & 1.55 & 0.020 & 15.17 \\
\hline 1.41 & 3.21 & 1.46 & 0.010 & 21.44 \\
\hline 1.19 & 2.24 & 2.44 & 0.006 & 28.26 \\
\hline 0.59 & 1.12 & 3.65 & 0.003 & 8.76 \\
\hline 0.297 & 0.57 & 4.94 & 0.001 & 4.78 \\
\hline Bottom & 1.18 & 1.12 & Bottom & 3.61 \\
\hline Initial & 100.00 & 100.00 & Initial & 1.31 \\
\hline
\end{tabular}

The majority (64.87\%) of the LPW particles by laser diffraction analyzer have particle sizes between 0.010 and $0.028 \mathrm{~mm}$ and only $0.36 \%$ by weight particles have sizes greater than $2 \mathrm{~mm}$. Therefore, the finest in terms of particle size distribution can be considered LPW, and the biggest - CDD.

\subsubsection{Chemical composition of the raw materials}

The chemical composition of the raw materials (Table 2), studied by the XRF method, is also significantly different. The IOT sample is mainly composed of $\mathrm{SiO}_{2}(41.9 \%)$ and $\mathrm{Fe}_{2} \mathrm{O}_{3}(48.1 \%)$ with a relatively small $\mathrm{Al}_{2} \mathrm{O}_{3}$ inclusion of $6.3 \%$ with calcination loss (C.L.) $3.08 \%$. According to Galvão, et al (2021), IOT is a dense material, mainly composed of iron oxides, silica, and alumina, and does not present harmful characteristics. 
Concrete waste $\mathrm{CDD}$ contains an even larger amount of $\mathrm{SiO}_{2}-49.1 \%$ and $\mathrm{CaO}=22.5 \%$ than IOT, due to the large amount of the main binding minerals of Portland cement calcium silicates (alite $3 \mathrm{CaO} \cdot \mathrm{SiO}_{2}$, belite $2 \mathrm{CaO} \cdot \mathrm{SiO}_{2}$ ) and calcium aluminum-ferrite $4 \mathrm{CaO} \cdot \mathrm{Al}_{2} \mathrm{O}_{3} \cdot \mathrm{Fe}_{2} \mathrm{O}_{3}$, as well as rocks as concrete filler. High C.L. $=10.60 \%$ of CDD can be explained by dissociation of carbonates and hydrates of concrete during calcination with a temperature of $1,000^{\circ} \mathrm{C}$.

Table 2

- Contents of the main oxides in the chemical composition of the raw

materials.

\begin{tabular}{|llll|}
\hline Oxides & $\begin{array}{l}\text { IOT, } \\
\text { wt. } \%\end{array}$ & $\begin{array}{l}\text { CDD, } \\
\text { wt. } \%\end{array}$ & $\begin{array}{l}\text { LPW } \\
\text { wt. } \%\end{array}$ \\
\hline $\mathrm{CaO}$ & 0.4 & 22.5 & 51.6 \\
\hline $\mathrm{MgO}$ & 0 & 6.4 & 29.0 \\
\hline $\mathrm{SiO}_{2}$ & 41.9 & 49.1 & 1.5 \\
\hline $\mathrm{Fe}_{2} \mathrm{O}_{3}$ & 48.1 & 1.9 & 0.2 \\
\hline $\mathrm{Al}_{2} \mathrm{O}_{3}$ & 6.3 & 6.4 & 0.1 \\
\hline $\mathrm{K}_{2} \mathrm{O}$ & 0.2 & 1.7 & $<0.1$ \\
\hline $\mathrm{SO}_{3}$ & $<0.1$ & 0.9 & $<0.1$ \\
\hline $\mathrm{MnO}$ & $<0.1$ & $<0.1$ & $<0.1$ \\
\hline $\mathrm{Na}_{2} \mathrm{O}$ & 0 & 1.5 & 0 \\
\hline $\mathrm{TiO}_{2}$ & 0 & 0.7 & 0 \\
\hline $\mathrm{P}_{2} \mathrm{O}_{5}$ & 0 & 0.5 & 0 \\
\hline $\mathrm{C} . \mathrm{L}$. & 3.1 & 10.6 & 17.6 \\
\hline $\mathrm{Total}$ & 100.0 & 100.0 & 99.9 \\
\hline
\end{tabular}

The main LPW oxides are $\mathrm{CaO}(51.6 \%)$ and $\mathrm{MgO}$ (29.0\%), which indicates the production of lime from dolomite rocks $\mathrm{Ca} \mathrm{Mg}\left(\mathrm{CO}_{3}\right)_{2}$ with a low amount (1.5\%) of $\mathrm{SiO}_{2}, \mathrm{Fe}_{2} \mathrm{O}_{3}-0.2 \%$ and $\mathrm{Al}_{2} \mathrm{O}_{3} 0.1 \%$ as pollutants. C.L. and these pollutants totaled $19.4 \%$, which significantly exceed the limit of $12 \%$ of the Brazilian technical standard NBR 6453 (2003) allowing to be classified as a lime production waste (LPW), but not as construction lime. IOT is a thin, dense material, mainly composed of iron oxides, silica, and alumina, and does not present harmful characteristics (Galvão, et al, 2021).

\subsubsection{Mineral composition of the raw materials by XRD method}


The study of the mineral composition of the initial components by XRD method showed that IOT (Fig. 1a) mainly consist of three ferruginous minerals - magnetite $\mathrm{Fe}_{3} \mathrm{O}_{4}$, hematite $\mathrm{Fe}_{2} \mathrm{O}_{3}$ and goetite $\mathrm{FeO}(\mathrm{OH})$ with inclusions of kaolinite $\mathrm{Al}_{4}\left(\mathrm{Si}_{4} \mathrm{O}_{10}\right) \cdot(\mathrm{OH})_{8}$ and quartz $\mathrm{SiO}_{2}$. The highest peak of the IOT curve of XRD belongs to the overlapped peaks of magnetite and hematite. The intensity scale Icps (counts per second) barely exceeds $200 \mathrm{cps}$, that means the minimum value of the crystalline minerals in IOT and maximum quantity of amorphous substances due to strong mechanical and chemical structural degradation compared two other raw materials. Similar effect of IOT's structural degradation was observed by Yao, et al (2020).

Mineral composition of concrete waste (Fig. 1 b) is presented by calcite $\mathrm{CaCO}_{3}$, albite $\mathrm{Na}\left(\mathrm{AlSi}_{3} \mathrm{O}_{8}\right)$ and quartz $\mathrm{SiO}_{2}$ with the highest scale Icps value until almost $800 \mathrm{cps}$. But the highest crystallin peak intensity at the angle $2 \Theta^{\circ}=26.8^{\circ}$ is presented by the overlap sum of calcite and quartz content diffractions. All others crystalline peaks of albite and quartz are rather low, but they are higher, than the peaks of IOW (Fig. 1a).

XRD of lime production waste (Figure 1-c) has the highest content of calcite with the principal independent peak at the angle $2 \Theta^{\circ}=29.2^{\circ}$ free from overlap with peaks of other minerals - lime $\mathrm{CaO}$, portlandite $\mathrm{Ca}(\mathrm{OH})_{2}$, magnesite $\mathrm{Fe}_{3} \mathrm{O}_{4}$ and quartz $\mathrm{SiO}_{2}$. Dolomite limestone served as a raw material for lime production, because the second mineral after calcite in the $\mathrm{LPW}$ used is magnesite $\mathrm{MgCO}_{3}$ with the highest peaks at $2 \Theta^{\circ}=33.8^{\circ}$ and $62.1^{\circ}$. The third most intense peaks at $2 \Theta^{\circ}=17.9^{\circ}$ and $50.9^{\circ}$ has a lime hydrate mineral portlandite $\mathrm{Ca}(\mathrm{OH})_{2}$. The quantity of $\mathrm{CaO}$ is $51.6 \%$ (Table 2), but lime as mineral is presented by the only independent small peak at $2 \theta^{\circ}=37.6^{\circ}$. Part of the lime can enter the amorphous phase of the sample, as well as part of amorphous and crystalline carbonates, but this information serves as irrefutable proof that this material will not serve as a commercial construction lime, but only as a lime production waste (NBR 6453, 2003).

\subsubsection{Microstructure of the raw materials (by SEM method)}

Micromorphology of the raw materials studied by the SEM method (Fig. 2) presents particles of different sizes and shapes, without physical and chemical connections between them. These shapes can be seen as rounded, oval, angular, laminar, needles, among others.

There is a large number of different sizes and shapes pores between the particles. Almost all particles have a rounded surface explained by the hydration during storage. IOW was formed (Fig. 2a) in the conditions of excessive water amount and long-term storage as sludge in industrial dumps, therefore, all edges and corners of its particles have a characteristic drip-like appearance; the concrete waste (Fig. 2b) was formed after hydration of the concrete mixture; and lime production waste (Fig. 2c) after firing actively adsorb moisture from the air during storage in unsatisfactory conditions of humid air. The only principal difference between the morphological microstructures of the particles' raw materials under study is the size of the biggest particles of CDD (till $10 \mu \mathrm{m}$ ) in comparison with $0.1-1 \mu \mathrm{m}$ of IOW and LPW particles. 


\subsection{DEVELOPED MATERIALS' CHARACTERIZATION 3.2.1 Axial resistance of the developed materials}

The analysis of the experimental results shows (Table 3 ) that the axial resistance of the test samples is directly proportional to LPW the content as a binder component and of the concrete waste, apparently due to the remainder hydraulic activity of the no hydrated amount of Portland cement minerals. Possibly the presence of these two chemically and hydraulically active components obscures the manifestation of the pozzolanic activity of CaO-activated iron ore tailings noted by Yao, et al (2020). The resistance of tested samples of all compositions steadily increases with an increase of hydration period from 0.42 $\mathrm{MPa}$ at 3rd day to $10.22 \mathrm{MPa}$ at 365th day.

Table 3

- Axial resistance of the tested samples during hydration and curing.

\begin{tabular}{|c|c|c|c|c|c|c|c|c|c|c|c|}
\hline \multirow[t]{2}{*}{$\mathrm{N}^{\circ}$} & \multicolumn{3}{|c|}{ Compositions, wt. \% } & \multicolumn{8}{|c|}{ Axial resistence (MPa) after days of curing } \\
\hline & IOT & CDD & LPW & 3 & 7 & 14 & 28 & 60 & 90 & 180 & 365 \\
\hline 1 & 30 & 60 & 10 & 0.93 & 1.15 & 1.73 & 1.94 & 2.27 & 2.91 & 3.14 & 4.26 \\
\hline 2 & 40 & 50 & & 0.72 & 1.07 & 1.57 & 1.80 & 1.92 & 2.22 & 3.90 & 4.70 \\
\hline 3 & 50 & 40 & & 0.56 & 0.82 & 1.14 & 1.34 & 2.17 & 2.06 & 4.01 & 4.38 \\
\hline 4 & 60 & 30 & & 0.42 & 0.84 & 1.26 & 1.31 & 1.83 & 2.19 & 3.53 & 4.16 \\
\hline 5 & 30 & 55 & 15 & 1.13 & 1.53 & 2.09 & 2.41 & 3.08 & 4.48 & 5.27 & 6.28 \\
\hline 6 & 40 & 45 & & 1.05 & 1.40 & 1.73 & 2.23 & 3.20 & 4.16 & 4.79 & 5.29 \\
\hline 7 & 50 & 35 & & 1.03 & 1.53 & 1.84 & 1.96 & 2.55 & 3.02 & 4.50 & 5.20 \\
\hline 8 & 60 & 25 & & 0.88 & 1.02 & 1.32 & 1.73 & 2.43 & 2.12 & 3.93 & 4.68 \\
\hline 9 & 30 & 50 & 20 & 1.68 & 2.49 & 3.05 & 3.94 & 5.72 & 6.55 & 7.67 & 9.90 \\
\hline 10 & 40 & 40 & & 1.53 & 1.85 & 2.51 & 2.92 & 3.46 & 5.55 & 7.93 & 9.22 \\
\hline 11 & 50 & 30 & & 0.86 & 1.24 & 2.18 & 2.83 & 3.11 & 4.65 & 6.07 & 8.90 \\
\hline 12 & 60 & 20 & & 0.75 & 1.63 & 2.20 & 2.52 & 2.90 & 4.20 & 5.40 & 7.07 \\
\hline 13 & 30 & 45 & 25 & 2.34 & 2.30 & 2.57 & 3.02 & 5.07 & 6.38 & 8.40 & 10.22 \\
\hline 14 & 40 & 35 & & 1.15 & 1.76 & 2.09 & 2.59 & 4.99 & 6.53 & 8.16 & 9.87 \\
\hline 15 & 50 & 25 & & 1.26 & 1.63 & 1.86 & 2.31 & 3.68 & 5.59 & 7.66 & 9.35 \\
\hline 16 & 60 & 15 & & 0.89 & 1.11 & 2.26 & 2.13 & 3.58 & 5.13 & 6.94 & 7.59 \\
\hline
\end{tabular}

The minimum strength at all ages of hydration and cure is possessed by test samples of composition 4 with a minimum $10 \%$ content of LPW and a minimum $30 \%$ content of CDD with a resistance of $4.16 \mathrm{MPa}$ 
on 365th days. Compositions 1, 2, and 3 also with 10\% LPW have slightly higher strengths, and remarkably similar strength values of composition 8 with 15\% LPW and minimum 25\% CDD. Samples of composition 13 with a maximum 25\% LPW content and 45\% CDD have the maximum resistance to 180 and 365 days of hydration ( 8.40 and $10.22 \mathrm{MPa}$ ). In the early stages, up to 90 days, only specimens of composition 9 had higher resistance.

The standard deviation values of the axial strength from the obtained experimental data never exceeded $5 \%$ of the average means.

\subsubsection{Expansion of the developed materials during curing}

Linear expansion of all developed materials (Table 4) enlarged with hydration time increasing due to the synthesis of sol-gel new formations on the surfaces of solid particles as result of their alkaline corrosion by LPW solutions. Filling the space between solid particles with sol leads to their expansion and an increase in the linear dimensions of the test samples during the first 28 days of the materials hydration. But after 28 days of increase in concentration, the sol transforms itself into a denser gel leading to the opposite process of shrinkage of the samples, starting on the 90th day of almost all compositions. Table 4 clearly shows the process of expansion of the samples to 28 days inclusive and shrinkage in all periods, including 365 days. Mymrin, et al (2019) studied in details a similar process of transition from expansion to shrinkage on ferrous metallurgy slags and in their interaction with various natural soils. But in some cases, expansion - shrinkage - expansion - shrinkage was repeated several times during 7 years of hydration and hardening when the samples were stored in air-humid conditions. At the same time, the strength continued to grow steadily. 
Table 4

Change of expansion coefficient of the test samples in the process of curing

\begin{tabular}{|c|c|c|c|c|c|c|c|c|c|c|c|}
\hline \multirow[t]{2}{*}{$\mathrm{N}^{\circ}$} & \multicolumn{3}{|c|}{ Compositions, wt. \% } & \multicolumn{8}{|c|}{ Axial resistence (MPa) after days of curing } \\
\hline & IOT & CDD & LPW & 3 & 7 & 14 & 28 & 60 & 90 & 180 & 365 \\
\hline 1 & 30 & 60 & \multirow[t]{4}{*}{10} & 0.93 & 1.15 & 1.73 & 1.94 & 2.27 & 2.91 & 3.14 & 4.26 \\
\hline 2 & 40 & 50 & & 0.72 & 1.07 & 1.57 & 1.80 & 1.92 & 2.22 & 3.90 & 4.70 \\
\hline 3 & 50 & 40 & & 0.56 & 0.82 & 1.14 & 1.34 & 2.17 & 2.06 & 4.01 & 4.38 \\
\hline 4 & 60 & 30 & & 0.42 & 0.84 & 1.26 & 1.31 & 1.83 & 2.19 & 3.53 & 4.16 \\
\hline 5 & 30 & 55 & \multirow[t]{4}{*}{15} & 1.13 & 1.53 & 2.09 & 2.41 & 3.08 & 4.48 & 5.27 & 6.28 \\
\hline 6 & 40 & 45 & & 1.05 & 1.40 & 1.73 & 2.23 & 3.20 & 4.16 & 4.79 & 5.29 \\
\hline 7 & 50 & 35 & & 1.03 & 1.53 & 1.84 & 1.96 & 2.55 & 3.02 & 4.50 & 5.20 \\
\hline 8 & 60 & 25 & & 0.88 & 1.02 & 1.32 & 1.73 & 2.43 & 2.12 & 3.93 & 4.68 \\
\hline 9 & 30 & 50 & \multirow[t]{4}{*}{20} & 1.68 & 2.49 & 3.05 & 3.94 & 5.72 & 6.55 & 7.67 & 9.90 \\
\hline 10 & 40 & 40 & & 1.53 & 1.85 & 2.51 & 2.92 & 3.46 & 5.55 & 7.93 & 9.22 \\
\hline 11 & 50 & 30 & & 0.86 & 1.24 & 2.18 & 2.83 & 3.11 & 4.65 & 6.07 & 8.90 \\
\hline 12 & 60 & 20 & & 0.75 & 1.63 & 2.20 & 2.52 & 2.90 & 4.20 & 5.40 & 7.07 \\
\hline 13 & 30 & 45 & \multirow[t]{4}{*}{25} & 2.34 & 2.30 & 2.57 & 3.02 & 5.07 & 6.38 & 8.40 & 10.22 \\
\hline 14 & 40 & 35 & & 1.15 & 1.76 & 2.09 & 2.59 & 4.99 & 6.53 & 8.16 & 9.87 \\
\hline 15 & 50 & 25 & & 1.26 & 1.63 & 1.86 & 2.31 & 3.68 & 5.59 & 7.66 & 9.35 \\
\hline 16 & 60 & 15 & & 0.89 & 1.11 & 2.26 & 2.13 & 3.58 & 5.13 & 6.94 & 7.59 \\
\hline
\end{tabular}

Composition 13 showed the highest shrinkage values at all curing days, followed by composites 14, 9 and 10 . This variance in results can be justified by the high content (till $70 \%$ in composite 9 ) of total amount of LPW and CDD with priority influence of LPW. Conversely, the lowest meaning of the expansion belongs to the composition 4, followed by composition 3 and 1, which has also the lowest resistance values on the 365th day (Table 2). These results confirm the idea of the relationship between the size variation and resistance of the test samples during physical and chemical processes of materials hydration. IOT in these composites plays the role of a passive filler. The standard deviation values of the experimental data obtained were varied between $0.02-0.04 \%$.

\subsubsection{Apparent density of the developed materials during curing}

The molding of the tested samples was through a compacting process, and this feature aims to improve the properties of the composite by reducing its voids by applying a pressing on the area, resulting in an 
increase in specific mass apparent.

Table 5

Apparent density of the tested samples after curing days.

\begin{tabular}{|c|c|c|c|c|c|c|c|c|c|c|c|}
\hline \multirow[t]{2}{*}{$\mathrm{N}^{\circ}$} & \multicolumn{3}{|c|}{ Compositions, wt. \% } & \multicolumn{8}{|c|}{ Apparent density $\left(\mathrm{g} / \mathrm{cm}^{3}\right)$ after curing days } \\
\hline & IOT & $\mathrm{CDD}$ & LPW & 3 & 7 & 14 & 28 & 60 & 90 & 180 & 365 \\
\hline 1 & 30 & 60 & \multirow[t]{4}{*}{10} & 3.52 & 3.53 & 3.53 & 3.54 & 3.54 & 3.56 & 3.58 & 3.65 \\
\hline 2 & 40 & 50 & & 3.46 & 3.46 & 3.47 & 3.47 & 3.49 & 3.53 & 3.58 & 3.64 \\
\hline 3 & 50 & 40 & & 3.53 & 3.67 & 3.67 & 3.68 & 3.69 & 3.69 & 3.69 & 3.70 \\
\hline 4 & 60 & 30 & & 3.50 & 3.51 & 3.51 & 3.53 & 3.55 & 3.59 & 3.68 & 3.70 \\
\hline 5 & 30 & 55 & \multirow[t]{4}{*}{15} & 3.50 & 3.52 & 3.46 & 3.47 & 3.48 & 3.52 & 3.57 & 3.63 \\
\hline 6 & 40 & 45 & & 3.49 & 3.45 & 3.52 & 3.54 & 3.56 & 3.58 & 3.60 & 3.63 \\
\hline 7 & 50 & 35 & & 3.53 & 3.52 & 3.52 & 3.51 & 3.53 & 3.56 & 3.60 & 3.62 \\
\hline 8 & 60 & 25 & & 3.54 & 3.54 & 3.55 & 3.57 & 3.58 & 3.61 & 3.68 & 3.71 \\
\hline 9 & 30 & 50 & \multirow[t]{4}{*}{20} & 3.47 & 3.47 & 3.48 & 3.49 & 3.53 & 3.54 & 3.56 & 3.58 \\
\hline 10 & 40 & 40 & & 3.49 & 3.49 & 3.50 & 3.51 & 3.52 & 3.53 & 3.55 & 3.59 \\
\hline 11 & 50 & 30 & & 3.48 & 3.49 & 3.49 & 3.50 & 3.52 & 3.54 & 3.58 & 3.61 \\
\hline 12 & 60 & 20 & & 3.52 & 3.53 & 3.54 & 3.56 & 3.58 & 3.64 & 3.67 & 3.73 \\
\hline 13 & 30 & 45 & \multirow[t]{4}{*}{25} & 3.45 & 3.49 & 3.49 & 3.50 & 3.50 & 3.52 & 3.55 & 3.57 \\
\hline 14 & 40 & 35 & & 3.48 & 3.48 & 3.48 & 3.49 & 3.49 & 3.51 & 3.53 & 3.59 \\
\hline 15 & 50 & 25 & & 3.47 & 3.47 & 3.48 & 3.49 & 3.52 & 3.53 & 3.56 & 3.59 \\
\hline 16 & 60 & 15 & & 3.54 & 3.56 & 3.58 & 3.57 & 3.60 & 3.62 & 3.65 & 3.74 \\
\hline
\end{tabular}

Results of apparent specific mass measuring and calculation (Table 4) demonstrate slow increasing within hydration time, especially at the early stage until 60 to 90 days. There is no constancy in the growth of the apparent specific mass in the early stages due to a rather slow process of corrosion of the alkaline solid particles and to the filling of pores' volumes. This process increased after 60 to 90 days, what is explained by the filling of the voids due to new formations between the initial grains' mix. The density value depends on the percentage of IOT content as the heaviest component of the initial mix. The standard deviation values of the experimental data obtained varied between $0.01-0.02 \mathrm{~g} / \mathrm{cm}^{3}$.

\subsubsection{Water absorption of the developed materials after the 28th and the 90th curing day}

All the mixtures investigated in this study differ only in the percentage of components, two of which (LPW and CDD) have residual bonding properties. Therefore, the main factor in the difference between their 
values of water absorption (Table 6) is the amount of hydraulically active elements that hydrated during the 28th and the 90th curing day and closed the previously open porosity of the test's samples with their newly hydrated formations.

Table 6

- Water absorption (wt. \%) after curing days

\begin{tabular}{|c|c|c|c|c|c|}
\hline \multirow[t]{2}{*}{$\mathrm{N}^{\circ}$} & \multicolumn{3}{|c|}{ Compositions, wt. \% } & \multicolumn{2}{|c|}{$\begin{array}{l}\text { Water absorption (wt. \%) } \\
\text { after curing days }\end{array}$} \\
\hline & IOT & CDD & LPW & 28 days & 90 days \\
\hline 1 & 30 & 60 & \multirow[t]{4}{*}{10} & 6.98 & 6.04 \\
\hline 2 & 40 & 50 & & 6.63 & 5.88 \\
\hline 3 & 50 & 40 & & 6.42 & 5.63 \\
\hline 4 & 60 & 30 & & 6.07 & 5.56 \\
\hline 5 & 30 & 55 & \multirow[t]{4}{*}{15} & 8.90 & 7.82 \\
\hline 6 & 40 & 45 & & 8.69 & 7.58 \\
\hline 7 & 50 & 35 & & 8.21 & 7.12 \\
\hline 8 & 60 & 25 & & 7.85 & 7.03 \\
\hline 9 & 30 & 50 & \multirow[t]{4}{*}{20} & 9.90 & 9.06 \\
\hline 10 & 40 & 40 & & 9.24 & 8.82 \\
\hline 11 & 50 & 30 & & 8.93 & 8.55 \\
\hline 12 & 60 & 20 & & 8.48 & 8.04 \\
\hline 13 & 30 & 45 & \multirow[t]{4}{*}{25} & 11.62 & 9.64 \\
\hline 14 & 40 & 35 & & 11.27 & 9.23 \\
\hline 15 & 50 & 25 & & 10.87 & 8.76 \\
\hline 16 & 60 & 15 & & 10.44 & 8.29 \\
\hline
\end{tabular}

Therefore, the values of water absorption of all compositions decreased between the 28th and the 90th days of hydration. Aggregates with a high percentage of LPW have higher values of water absorption due to incomplete hydration of lime during test's samples preparation and hardening. For example, the size of compositions 1 - 4 with 10\% LPW on the 28th day varies between 6.98 and $6.07 \%$, while formulations $13-$ 16 with $25 \%$ LPW are between $11.62-10.44 \%$. This difference decreased considerably at the 90 th hydration day: $6.04-5.56 \%$ versus $9.64-8.29 \%$.

The values of water absorption for compositions with the same amount of LPW increased when CDD values rose. Test's samples of composition 13 presented between 11.62 and $9.64 \%$ of maximum water 
absorption; a minimum varying from 6.07 to $5.56 \%$ was measured in composition 4 , respectively at the 28th and 90th day.

The standard deviation values of water absorption coefficient values never exceeded $0.07 \%$.

\subsection{STRUCTURE FORMATION PROCESSES OF THE DEVELOPED COMPOSITES}

To study the physical-chemical processes of the developed materials' structures formation, composition 12 was chosen due to the higher content ( $60 \%$ wt.) of IOT as the most hazardous component with almost minimum (20\%) CDD and medium (20\%) content of binder element - LPW. In addition, composition 12 samples have rather high values of axial resistance, which correspond to the demands of Brazilian technical norms NBR 15116 (2004) and therefore can be recommended for industry application.

The set of methods to study the structure formation processes of the composition 12 for 365 days hydration and cure consisted of XRD, SEM, EDS and mapping. The environmental properties were studied using AAS metal's leaching and solubility methodology, isotopic composition by micro mass laser spectroscopy (LAMMA) method at the 90th day of test's sample curing

\subsubsection{Changing composition 12 mineralogical mixture}

The mineralogical composition of the initial dry mixture of composition 12 consists of the following minerals: portlandite $\mathrm{Ca}(\mathrm{OH})_{2}$, calcite $\mathrm{CaCO}_{3}$, hematite $\mathrm{Fe}_{2} \mathrm{O}_{3}$, magnetite $\mathrm{Fe}_{3} \mathrm{O}_{4}$ and quartz $\mathrm{SiO}_{2}(\mathrm{Figure}$ 3a). Maximum intensity, almost 3,000 cps (calculations per second), of the crystalline peaks has quartz in the angle $2 \Theta^{\circ}=26.5^{\circ}$. Other minerals highest levels are $500 \mathrm{cps}$ or less, except for the calcite, which is $29.5^{\circ}$ at a $2 \Theta^{\circ}$ angle. X-ray background is highly visible as well which means a high content of the amorphous materials of composition 12. Almost all quartz particles have superficial mechanically destructed crystal structure layers and beneath them non-destructed mono-crystalline nuclei. Such surface destruction occurred during many geological periods in the dynamic regime of the earth's crust, temperature changes, water and wind currents with particles friction. These structures destroyed layers twice scattered $x$-rays intensity: falling on the sample and reflected by the nuclei of the sample, and thus significantly reduces the intensity of $x$-rays peaks of diffractogram pattern of the Figure 3a, giving the wrong impression of a lower content of all minerals, including quartz Mymrin, et al (2019).

In Figure $3 \mathrm{~b}$ of the composition samples 12 the surface layers of quartz were chemically dissolved for 180 days in an alkaline environment of hydrated lime residue; the products of this dissolution were removed in pore space as part of the amorphous sol-gel process. Synthesis of amorphous $\mathrm{C}-\mathrm{S}-\mathrm{H}$ gel during CaO-activation of iron ore tailings was marked by Yao, et al (2020). Similar synthesis of amorphous new formation of the materials with till $50 \%$ of iron ore tailings contents was studied by Galvão, et al (2018); Yang, et al (2019) used alkali-silica gel reaction of mortars prepared with the traditional wet-mix. 
After hydration and open-air curing in the diffractogram (Figure 3b) the peaks of portlandite disappear turning into calcite $\left(\mathrm{CaCO}_{3}\right)$. The intensities of calcite peaks increased at almost all angles, particularly the peak at angle $2 \theta^{\circ}=29.5^{\circ}$ grows from I $= \pm 1,200$ to $\pm 1,500 \mathrm{cps}$ due to the carbonization process of lime production waste and to the increase of calcite $\left(\mathrm{CaCO}_{3}\right)$

The process of all materials strengthening continues up to 365 days at a slow speed (Table 3). In Figure $3 c$, the visible increase in intensities of crystalline peaks of quartz and calcite. The largest of these quartz peaks at an angle of $2 \theta^{\circ}=26.5^{\circ}$ increase their intensity from value I $= \pm 2,800$ cps to the level of $\pm 3,000$ cps. The calcite peak with angle $2 \theta^{\circ}=29.5^{\circ}$ grows slightly slower in this time frame than during the first 180 days - from \pm 1500 cps to $\pm 1,700$ cps.

A very high background of all three diffractograms is also well visible in Figure 3, which means a high content of amorphous materials. They were partially inherited from the initial amorphous components (Figure 1), but a significant part was formed during the alkaline dissociation of all particles in the initial mixture, including that of quartz particles.

\subsubsection{Changing composition 12 samples micro morphology during hydration and cure}

The process of the micro morphological structure changing of the composition 12 samples during hydration and cure was studied using the SEM method (Figure 4). The compacted dry sample of composition 12 (Figure 4a) is represented by particles of various configurations - round, oval, angular, needles, curved lamellar, among others. The particles with the size 1 - $200 \mu \mathrm{m}$ are not linked together; the pores between them also have different sizes and shapes.

After 180 hydration days all particles are covered (Figure 4b and c) with a layer of gel-like material, sticking all particles together, which was not found in the original dry mix (Figure 4a). Under this layer, one can find the configurations of the initial particles. The number of pores has been drastically reduced, and their shapes have become smooth and rounded on all sides. The pore's sizes also drastically decreased and vary between 1 and $10 \mu \mathrm{m}$. This transition of dispersed and unconnected particles (Figure 4a) for their unification in monolithic structures (Figures 4-b, c, d and e) with density increasing (Table 5), simultaneous decreasing of water absorption values (Table 6) of these new formations' layers explains the increase in the resistance of materials (Table 3 ) in the forming these bonds.

The microstructure of the test samples at some points with bigger magnification (Figure 4c and $\mathrm{f}$ ) is significantly different due to the impossibility of obtaining equal homogeneity at the micro level of the initial components' mixes. They also clearly show the process of gathering and combining particles in small flakes and short crystal-like new formations' needles over more monolithic areas, which leads to an increase in the resistance of the samples.

Much more of these crystal-like new needles and their druses appeared in the samples after 365 days of hydration (Figure 4f), which increased their resistance as well. 
But the number of such points is relatively small and the overwhelming number of structural morphologies of the samples is characterized by the test samples' structure in Figures $4 \mathrm{~d}$ and especially $4 \mathrm{e}$ - completely flat, without any resemblance to the existence of individual initial particles and with a very limited number of small pores in gel-like amorphous structures of new formations.

The sol-gel transition was observed in this study for 365 days, but it can continue for 7 or more years Mymrin, et al (2019), especially in conditions of sufficient humidity which causes long-term hardening and changes in other mechanical, physical and chemical properties of the developed materials.

\subsubsection{Microchemical composition of new formations 12}

The results of the chemical composition obtained in Figure $4 d$, e and $f$ using the energy dispersion spectroscopy (EDS) method, are presented in Table 7. They demonstrate that new formations in the points 1 - 4, obtained in needles (Figure 4d), have a high level of Ca content (between 30.01 and 30.88\%) and carbon C (between 24.11 and $25.44 \%$ ), followed by Fe (15.34 0-25.56\%). This coincidence of needle shapes, their frequent druses - shaped intergrowths and a constant composition, predominantly $\mathrm{Ca}-\mathrm{C}$, allows us to attribute them to $\mathrm{CaCO}_{3}$ calcite. The validity of this assumption is confirmed by the results of the XRD analysis (Fig. 3b and c). High levels of those elements, especially $\mathrm{Fe}$, Si and small inclusions of $\mathrm{Mg}$ and $\mathrm{Al}$ are inevitable in points 1 - 4 due to their high levels in the initial raw materials. Studying the processes of activation of hydration properties of iron ore tailings as supplementary cementitious materials in cement, Yao, et al (2020) observed the synthesis of similar crystals and assigned them to the group ettringite $\mathrm{Ca}_{6} \mathrm{Al}_{2}\left(\mathrm{SO}_{4}\right)_{3}(\mathrm{OH})_{12} \cdot 26 \mathrm{H}_{2} \mathrm{O}$. But the maximum amount of $\mathrm{SO}_{3}=0.9 \%$ in CDD (Table 2), with $20 \%$ of CDD contain in the composition 12 (Table 3 ). Therefore, the ettringite synthesis in the initial mix with such a small amount of $\mathrm{SO}_{3}$ was practically excluded or at least could not be fixed in our study due to the low sensitivity of the XRD method (about $5 \%$ ).

Table 7 - Chemical composition of new composition formations 12 at points in Figure $4 d$, e and $f$ (by the EDS method).

\begin{tabular}{|lllllllll|}
\hline Points & $\mathrm{C}$ & $\mathrm{Mg}$ & $\mathrm{Al}$ & $\mathrm{Si}$ & $\mathrm{Ca}$ & $\mathrm{Fe}$ & $\mathrm{Cu}$ & Total \\
\hline 1 & 25.24 & 6.45 & 0.70 & 21.02 & 30.88 & 15.34 & 0.37 & 100.00 \\
\hline 2 & 25.44 & 5.99 & 0.64 & 12.05 & 30.01 & 25.56 & 0.31 & 100.00 \\
\hline 3 & 25.33 & 8.09 & 0.58 & 10.91 & 30.16 & 24.59 & 0.32 & 100.00 \\
\hline 4 & 24.11 & 3.18 & 0.26 & 20.74 & 30.17 & 22.54 & - & 100.00 \\
\hline 5 & 12.64 & 12.16 & - & 0.78 & 20.63 & 53.80 & - & 100.00 \\
\hline 6 & 14.18 & 12.72 & 0.26 & 0.73 & 18.00 & 53.75 & 0.36 & 100.00 \\
\hline 7 & 15.65 & 4.66 & 11.44 & 1.24 & 11.67 & 54.89 & 0.45 & 100.00 \\
\hline 8 & 15.67 & 4.62 & 11.65 & 1.19 & 11.82 & 55.05 & - & 100.00 \\
\hline
\end{tabular}


Points 5 - 8 of new formations have a predominance of Fe (between 53.75 and $55.05 \%$ ) due to the predominance of Fe (48\%) in IOT sludge and high content (60\%) in composition 12 in the form of hematite and magnetite (Fig. 3). High carbon content C (12.64 - 15.67\%) at points 5 - 8 confirm the possibility of the existence of amorphous carbonates, as an amorphous background part of the diffractograms of Figure $3 b$ and $c$.

\subsubsection{Distribution of the main chemical elements in the new composition 12 formations (by mapping method)}

The study of the distribution order of the chemical elements in the surface layer of new formations of the composition samples 12 was carried out using the mapping method (Figure 5) with 1,000 times magnification. The results obtained show the presence of a locally high concentration of Fe, $\mathrm{Al}$ and $\mathrm{Si}$ atoms concentrated in the form of misshapen clots.

Much more evenly distributed $\mathrm{Ca}$ and Mg particles. Such an uneven distribution of chemical elements over the volume of samples can be explained mainly by three reasons: 1. practical impossibility of achieving a high level of homogenization at the micro level when mixing dry initial component; 2 . the presence of crystalline forms of minerals both in the initial raw materials (Fig. 1) and at the end of chemical interaction of the components in a humid alkaline environment (Fig. 3); 3. alkaline corrosion of the surface of solid particles and the occurrence of the sol-gel process contributes to the homogenization of the chemical composition of the samples but cannot lead to its radical improvement.

\subsubsection{Isotopic chemical composition in new formations of the composition 12 by LAMMA method}

The heterogeneity of the chemical composition of the gel new formations was also confirmed by the method of laser micro-mass analysis (LAMMA) of six points closest to each other of the sample of composition 12 after 90 days of hydration (Fig. 6). The set of isotopes and their intensity at each of the new formations was significantly different from each other, also detected by the EDS method (Table 7). As the most sensitive analytical method, LAMMA helped to detect the presence of not only Cu (Table 2), but also the presence of other heavy metal isotopes ( $\mathrm{Cr}$, and $\mathrm{Zn}$ ) in most of the points of new formations (Fig. 6).

\subsection{Sustainability of developed composites}

Environmental properties of the developed materials were studied by atom absorption spectroscopy (AAS) methods after samples' leaching and solubility in acid environment (NBR 10,004 - 2014). The efficiency of the heavy metals' chemical binding was verified by comparing the AAS results of the initial IOT as more polluted raw material (Figure 5 and Table 2) and composition 12 with a maximum 60\% IOT content.

The hazardous IOT leaching study (Table 7) showed that the content of metals, including heavy metals ( $\mathrm{Zn}, \mathrm{Ni}, \mathrm{Ba}, \mathrm{Cd}, \mathrm{Pb}, \mathrm{Sn}, \mathrm{Hg}, \mathrm{Se}, \mathrm{Cr}$, etc.) far exceeded the toxicity limit established by Brazilian norms NBR 
10,004 (2014).

Table 8 - Leaching and solubility of IOT sludge and composition 12 metals on the 90th curing day (using the AAS method).

\begin{tabular}{|lllllll|}
\hline \multirow{2}{*}{ Elements } & \multicolumn{2}{l}{ Leaching, $\mathrm{mg} / \mathrm{L}$} & \multicolumn{4}{l|}{ Solubility, mg/L } \\
\cline { 2 - 7 } & $\begin{array}{l}\text { IOT } \\
\text { sludge }\end{array}$ & Comp.12 & NBR & IOT & Comp. 12 & NBR \\
& 2.63 & 0.47 & 0.05 & 2.63 & $<0.001$ & 0.01 \\
\hline $\mathrm{As}$ & 55.28 & 12.03 & 70.0 & 4.47 & 0.052 & 0.7 \\
$\mathrm{Ba}$ & 1.14 & 0.05 & 0.5 & 1.71 & $<0.005$ & 0.005 \\
$\mathrm{Cd}$ & 3.43 & 0.32 & 1.0 & 3.66 & $<0.01$ & 0.01 \\
$\mathrm{~Pb}$ & 8.46 & 1.78 & 5.0 & 8.67 & 0.02 & 0.05 \\
\hline $\mathrm{Cr}$ total & 2.47 & 0.04 & 0.1 & 3.81 & $<0.001$ & 0.001 \\
\hline $\mathrm{Hg}$ & 2.75 & 0.23 & 1.0 & 3.35 & $<0.001$ & 0.01 \\
\hline $\mathrm{Se}$ & 4.76 & 2.56 & $*$ & 36.44 & 0.05 & 0.2 \\
\hline $\mathrm{Al}$ & 6.29 & 0.19 & $*$ & 7.08 & 1.47 & 2.0 \\
\hline $\mathrm{Cu}$ & 28.31 & 1.69 & $*$ & 30.75 & 0.09 & 0.3 \\
\hline $\mathrm{Fe}$ & 5.11 & 0.85 & $*$ & 7.43 & 0.06 & 0.1 \\
\hline $\mathrm{Mn}$ & 4.48 & 0.03 & $*$ & 14.13 & 1.72 & 5.0 \\
\hline $\mathrm{Zn}$ & & & & & & \\
\hline
\end{tabular}

Results of the composition 12 meet the requirements of Brazilian norms NBR 10,004 (2014) after 90 days hydration and cure. For example, barium $(\mathrm{Ba})$ leaching values are 4.6 times less than IOT as a raw material and 5.7 times less than required by NBR 10,004 (2014). Cadmium (Cd) leaching has a similar decrease in values by 22.8 and 10 times, etc. Other metals also have a similar decrease in leach values. The solubility values of IOT sludge arsenic (As) before use as the main raw material have much higher values $(2.63 \mathrm{mg} / \mathrm{L}$ ) than $0.01 \mathrm{mg} / \mathrm{L}$ required by NBR 10,004 (2014); but after chemical bonding in composition 12 the solubilization value decreased to $<0.001 \mathrm{mg} / \mathrm{L}$. Such decrease in leaching and solubility of IOT and composition 12 can be explained by two reasons: 1. dilution of the number of metals from $100 \%$ in IOT till $60 \%$ in the composition 12; 2 . reliable chemical bonding in insoluble condition or strong encapsulation of metals in sol-gel new formations for 90 days.

\section{Conclusions}

1. It was experimentally confirmed the possibility of iron ore treatment (IOT) sludge in composites with concrete waste (RC) and lime production waste (LPW) application to produce sustainable road bases, 
concrete blocks and solid unburned bricks, among other sustainable construction materials.

2. The mechanical and physical properties of materials developed correspond to the demands of technical standards in Brazil. Particularly, the values of axial resistance on the 3rd day of hydration and curing varies between $0.56-2.34 \mathrm{MPa}$, on the 28th day between 1.31 - 3.94 MPa, on the 180th day - 3.14 $\mathrm{MPa}$, and $4.16-10.22 \mathrm{MPa}$ on the 365th day. The values of the coefficient of linear expanding during the first 3 days fluctuated between 1.56 and $2.14 \%$, up to $1.82-2.51 \%$ on the 28 th day and then decreased to $1.58-2.22 \%$ on the 365 th day. Water absorption on the 28 th day was between 6.07 and $11.62 \%$, decreasing till $5.66-9.64 \%$ on the 90th day. All these variations are in accordance with technical Brazilian norms.

3. It can be argued that the structure formation process of the new developed composites consists of two mutually complementary effects:

a. The effect of alkaline dissociation on the surface of solid particles with synthesis of new amorphous sol-gel formations (also known as "solid solutions"), gradually transforming into a rock-like state, like a large amount of well-known natural materials - silica, opal, obsidian, perlite, pumice, amber, flask, etc.

b. The effect of the synthesis of carbonates, especially calcite with possibly low crystalline and amorphous dolomite content, is clearly visible. Both types of new formations (amorphous and crystalline), as in nature, are mixtures of varying degrees of homogeneity both initially dissolved components and of the products of their interaction in the porous space.

The study of the physical - chemical processes of structures formation with these properties by the methods of X-rays diffraction, scanning electron microscopy, micro chemical composition through the method of energy dispersion system, of the chemical elements' distribution by mapping method and isotope content of metals by LAMMA method in the surface layer of new formations, allowed to establish the implementation of the following processes: chemical corrosion of the solid particles' surfaces of the initial components in an alkaline solution of hydrated lime production residue; chemical interaction of these solutions of the initial components with the formation of sol solutions of various chemical compositions; the densification of these solid solutions with their transition to a gel; the synthesis of calcite crystals in pore space; the transition of the gel during a year of hydration in the stone-like state. These processes explain the change in all mechanical and physical properties of the materials developed throughout the year.

4. It was found that iron ore treatment waste contains significant amounts of metals, including hazardous heavy metals $(\mathrm{Zn}, \mathrm{Ni}, \mathrm{Ba}, \mathrm{Cd}, \mathrm{Pb}, \mathrm{Sn}, \mathrm{Hg}, \mathrm{Se}, \mathrm{Cr}$ ) in quantities above brazilian sanitary norms. The study of the ecological properties of the developed materials by standard methods of solubility and leaching in an acid medium demonstrated the flow of sol-gel bonding process with the synthesis of new formations up to the level that satisfies the sanitary norms. Therefore, the greatest benefit from the application of the results obtained is the environment, considering the real possibility of using industrial 
waste as raw material, applying an appropriate final destination, preventing possible contamination of the environment and reducing the extraction of natural resources.

\section{Declarations}

1. Declare that our manuscript was not published and not submitted elsewhere

a. We declare absence any conflicts of interest

b. We confirm compliance with all ethical standards (include appropriate approvals or waivers)

c. Data of the materials available (data transparency)

d. Code availability (software application or custom code) - Not applicable

e. Ethics approval (include appropriate approvals or waivers)-

f. We confirm the consent to participate

g. All co-authors consent for publication

h. Authors' contributions (optional):

Vsévolod Mymrin - author of the idea, developer of the plan of the experiments, participant of all stages of research, co-author of the manuscript

Ana Povaluk, performer of all laboratory experimental works, co-author of the report

Luana Cechin, co-author of the bibliographic revision and performer of laboratory works

Monica A. Avanci - performer of all laboratory experimental works, co-author of the report and of this manuscript

Paulo H.B. Rolim - performer of all laboratory experimental works, co-author of the report and of this manuscript.

Cleber L. Pedroso - bibliographical revision and performer of XRD analyses

Daniela E. Pedroso - bibliographical revision and performer of SEM analyses

Karina Q. Carvalho - performer of all laboratory experimental works, co-author of the report and of this manuscript

Vsévolod Mymrin

Corresponding author 


\section{References}

1. Akhtar A, Sarmah AK (2018) C\&D waste generation and properties of recycled aggregate concrete: a global perspective J Clean Prod 186:262-281. https://doiorg/101016/jjclepro201803085

2. Baldovino JJA, Izzo RLS, Rose JL, Domingos MDI (2021) Strength, durability, and microstructure of geopolymers based on recycled-glass powder waste and dolomitic lime for soil stabilization. J Con Build Mat 271:121874. https://doiorg/101016/jconbuildmat2020121874

3. Bassani M, Tefa L, Coppola B, Palmero P (2019) Alkali-activation of recycled construction and demolition waste aggregate with no added binder. J Con Build Mat 205:398. - 413 DOI: 101016/jjclepro201906207

4. El-Naggar KAM, Amin ShK, El-Sherbiny SA, Abadir MF (2019) Preparation of geopolymer insulating bricks from waste raw materials. J Con Build Mat 222:699-705.

https://doiorg/101016/jconbuildmat201906182

5. EU (2018) Construction and Demolition Waste Protocol and Guidelines.

https://eceuropaeu/growth/content/eu-construction-anddemolition-waste-protocol-0_en Accessed on July 17, 2019

6. Fatemi S, Imaninasab R (2016) Performance evaluation of recycled asphalt mixtures by construction and demolition waste materials, J Con Build Mat 120, 450-456 https://doiorg/101016/jconbuildmat201701055

7. Fontes WC, Mendes JC, Da Silva SN, Peixoto RAF (2016) Mortars for laying and coating produced with iron ore tailings from tailing dams, J Con Build Mat 112:988-995. https://doiorg/101016/jconbuildmat201603027

8. Freitas CM, Barcellos C, Asmus CIRF, Silva MA, Xavier DR (2019) From Samarco in Mariana to Vale in Brumadinho: mining dam disasters and Public Health. J Cadernos de Saúde Pública 35:5 http://dxdoiorg/101590/0102-311x00052519

9. Galvão JL, Andrade HD, Brigolini GJ, Peixoto RAF, Mendes JC (2018) Reuse of iron ore tailings from tailings dams as pigment for sustainable paints, J Clean Prod 200:412-422. https://doiorg/101016/jjclepro201807313

10. Huanga B, Wang H, Kuac H, Gengd Y, Bleischwitze R, Ren J (2018) Construction and demolition waste management in China through the 3r principle. J Res Cons Rec 129:36-44. http://dxdoiorg/101016/jresconrec201709029:IPT Rejeitos de mineração 2019 http://wwwiptbr/noticias_internaphp?id_noticia=1043

11. Karanac M, Đolić M, Veljović $Đ$, Rajaković-Ognjanović V, Veličković Z, Pavićević V, Marinković $A$ (2018) The removal of $\mathrm{Zn}^{2+}, \mathrm{Pb}^{2+}$, and $\mathrm{As}(\mathrm{V})$ ions by lime activated fly ash and valorization of the exhausted adsorbent, J Was Man 78:366-378 https://doiorg/101016/jwasman201805052

12. Luo L, Zhang $Y, B a o ~ S$, Chen $T$ (2016) Utilization of iron ore tailings as raw material for Portland cement clinker production, J AdvMatSciEng, 1596047. https://doi.org/101155/2016/1596047 
13. Mymrin V, Aibuldinov K, Alekseev K et al (2019) Sustainable stabilization/solidification of Kazakhstan's natural loam by hazardous ground cooled ferrous slag activated by lime production waste to produce efficient road base material, J Clean Prod 231:1428-1436 doi org/101016/jjclepro201905250

14. NBR 6453 (2003) Cal virgem para construção civil -. Requisitos Rio de Janeiro

15. NBR 10,004, Solid waste - Classification Rio de Janeiro, 2014

16. NBR 15116 (2004) Recycled aggregates from solid civil construction waste - Use in paving and concrete preparation without structural function -. Requirements Rio de Janeiro

17. Pahlavan P, Manzi S, Rodriguez-Estrada MT, Bignozzi MC (2017) Valorization of spent cooking oils in hydrophobic waste-based lime mortars for restorative rendering applications, J Con Build Mat 146:199-209 https://doiorg/101016/jconbuildmat201704001

18. Pedroso CL, Brasil (2019) http://wwwinstitutoventuriorgbr/ojs/indexphp/firs/article/view/1687[

19. Robalo K, Costa H, Carmo R, Júlio E (2021) Experimental development of low cement content and recycled construction and demolition waste aggregates concrete, J Con Build Mat, 273, 121680 https://doiorg/101016/jconbuildmat2020121680

20. Shettima AU, Hussin MW, Ahmad Y, Mirza J (2016) Evaluation of iron ore tailings as replacement for fine aggregate in concrete, $\mathrm{J}$ Con Build Mat 120:72-79.

https://doiorg/101016/jconbuildmat201605095

21. Silva RV, de Brito J, Dhir RK (2014) Properties and composition of recycled aggregates from construction and demolition waste suitable for concrete production, J Con Build Mat 65, 201-217. http://dxdoiorg/101016/jconbuildmat201404117

22. Wang K, Larkin T, Singhal N, Zhuang T (2019) Amendment of municipal sewage sludge with lime and mussel shell: Effects on fate of organic matter and pharmaceutically active compounds, J Was Man, 85:272-282 DOI: 101016/jwasman201812035

23. Wise Uranium (2015) The Los Frailes Tailings Dam Failure. Aznalcóllar, Spain

24. Xiao R, Polaczyk P, Jiang X, Zhang M, Wang Y, Huang B (2021) Cementless controlled low-strength material (CLSM) based on waste glass powder and hydrated lime: Synthesis, characterization and thermodynamic simulation J Con Build Mat 275:122157 https://doiorg/101016/jconbuildmat2020122157

25. Xiong C, Li W, Jiang L, Wang W, Guo Q (2017) Use of grounded iron ore tailings (GIOTs) and BaCO3 to improve sulfate resistance of pastes. J Con Build Mat 150:66. - 76 DOI: /jconbuildmat201705209

26. Xuan D, Sun C, Zheng W (2018) Management and sustainable utilization of processing wastes from ready-mixed concrete plants in construction: a review, J Res Cons Rec 136:238-247. https://doiorg/101016/jresconrec201804007

27. Yang S, Poon CH, Ling TC (2019) Distribution of ASR gel in conventional wet-mix glass mortars and mechanically produced dry-mix glass blocks, J Con Build Mat 229:116916 doiorg/101016/jconbuildmat2019116916 
28. Yao G, Wang Q, Wang Z, Wang J, Lyu X (2020) Activation of hydration properties of iron ore tailings and their application as supplementary cementitious materials in cement. J PowTech 360:863$871 \mathrm{https}: / /$ doiorg/101016/jpowtec201911002

29. Zhang N, Zhang N, Duan HB, Huo PS, Zheng LN, Zhang H (2017) Characterizing the generation and flows of construction and demolition waste in China. J Con Build Mat 136:405-413. : 101007/978981-15-3977-0_72

30. Zhou Y, Lu J, Li J, Cheeseman C, Poon CS (2021) Influence of seawater on the mechanical and microstructural properties of lime-incineration sewage sludge ash pastes, J ConBuildMat 278: 122364 https://doiorg/101016/jconbuildmat2021122364

\section{Figures}




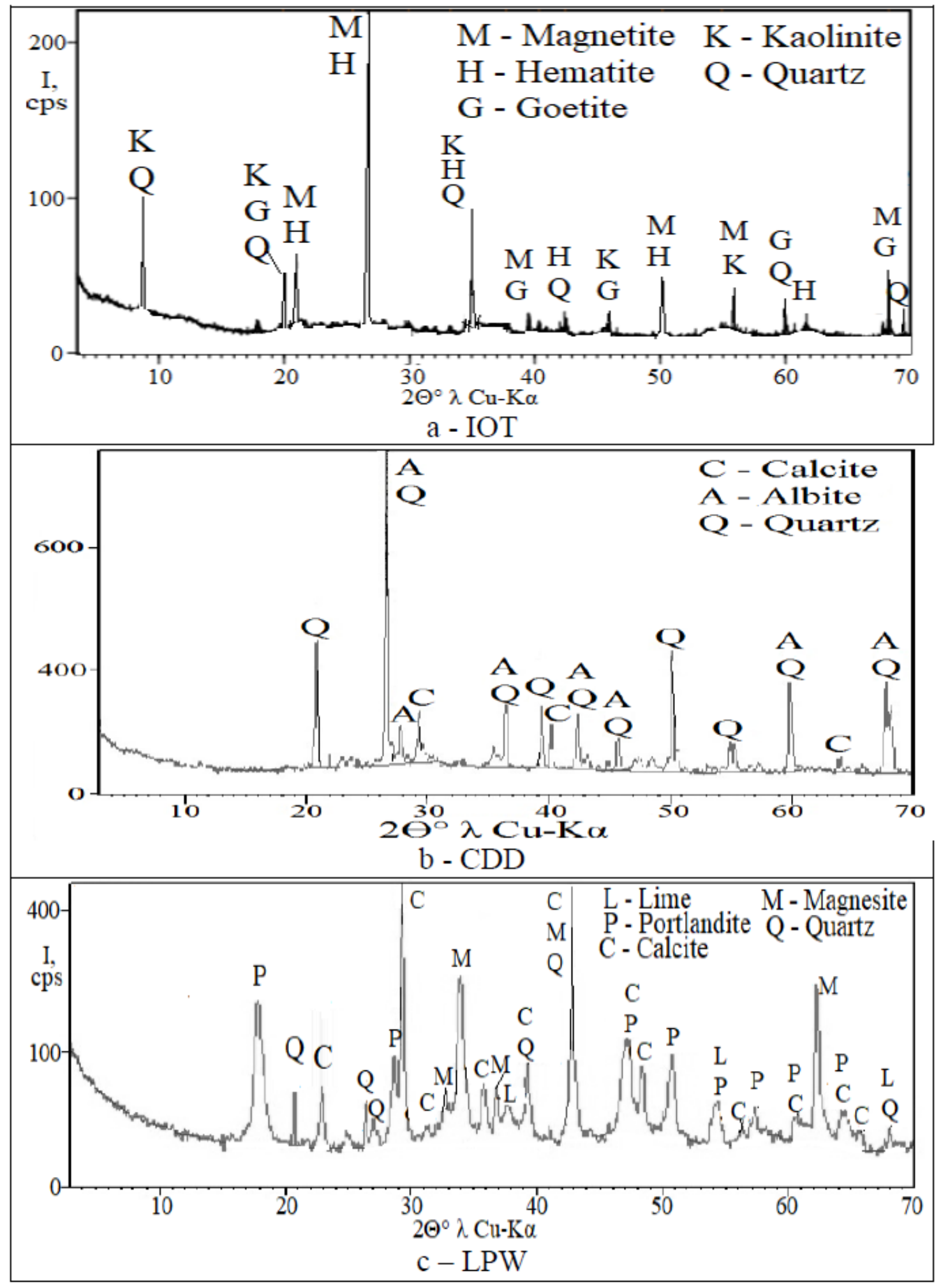

Figure 1

XRD patterns of the raw materials: $a$ - iron ore treatment waste, $b$ - concrete production and demolition debris and c - lime production wastes. 


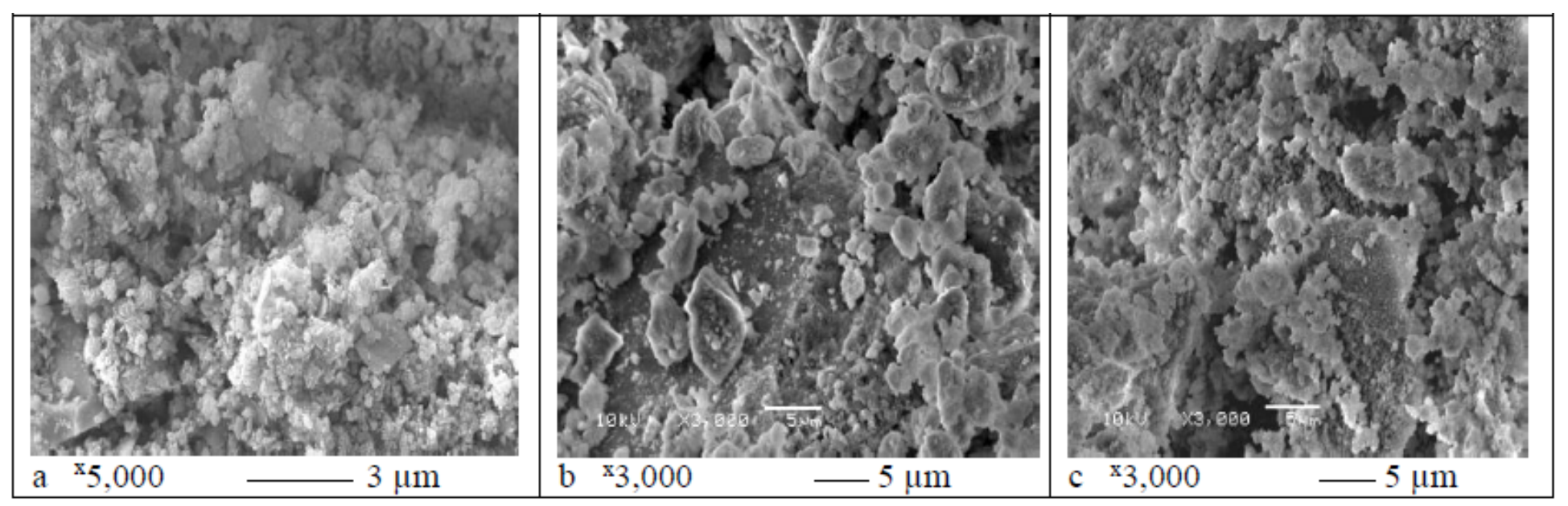

Figure 2

Microstructure morphology of the raw materials: $\mathrm{a}$ - iron ore treatment waste, $\mathrm{b}$ - concrete production and demolition debris and c - lime production wastes. 


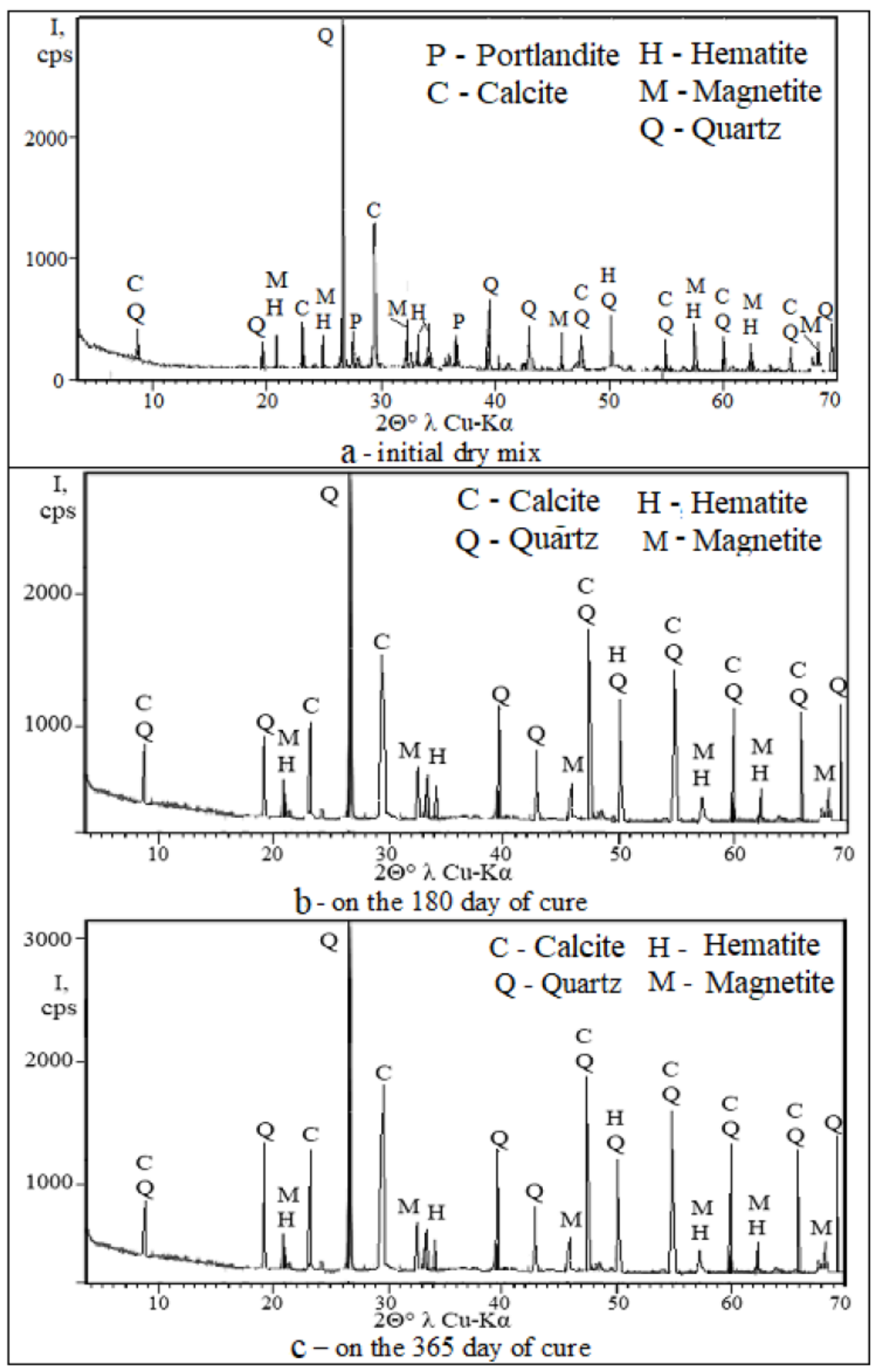

Figure 3

XRD patterns of the composites 12 test samples: a - initial dry mix; b - on the 180th and $c$ - on the 365th curing days. 


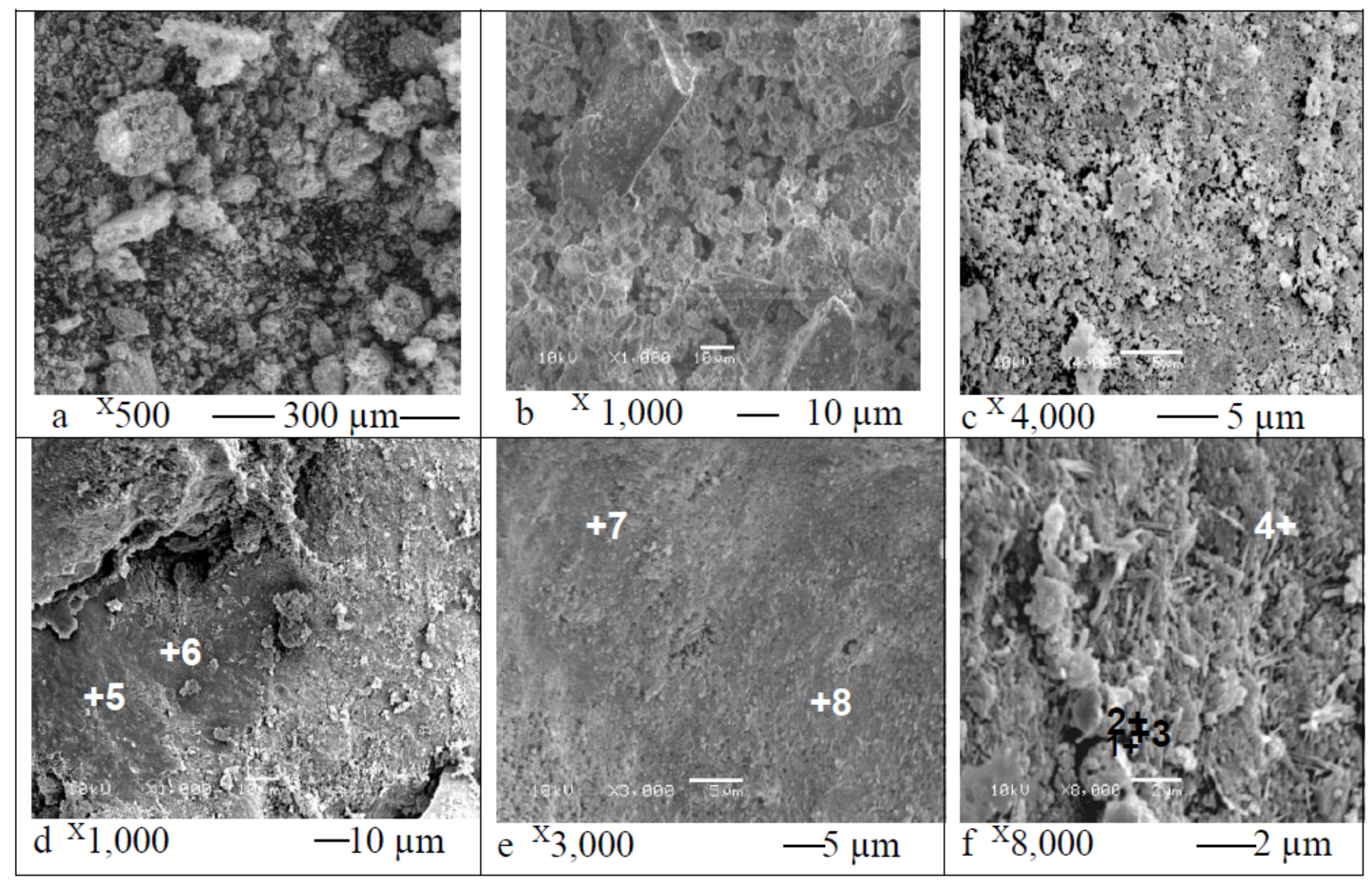

Figure 4

Change of the morphological microstructure of the composition 12 samples by the SEM method: a initial dry mixture; $b$ and $c$ - after 180 days of curing; $d$, $e$ and $f$ - after 365 days of curing and points of micro chemical composition by the EDS method. 


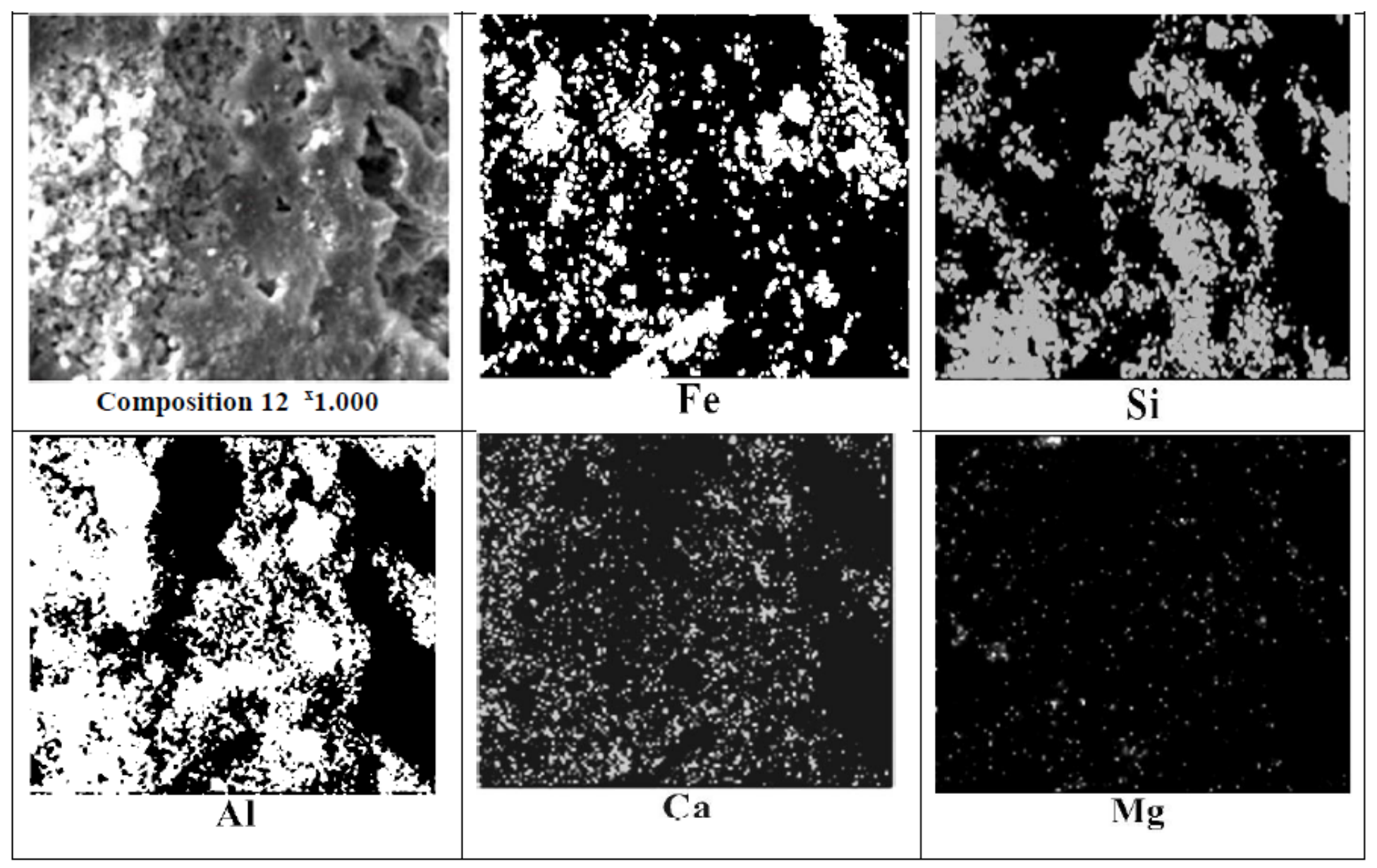

Figure 5

Main chemical elements distribution in new formations of the composition 12 by mapping method. 

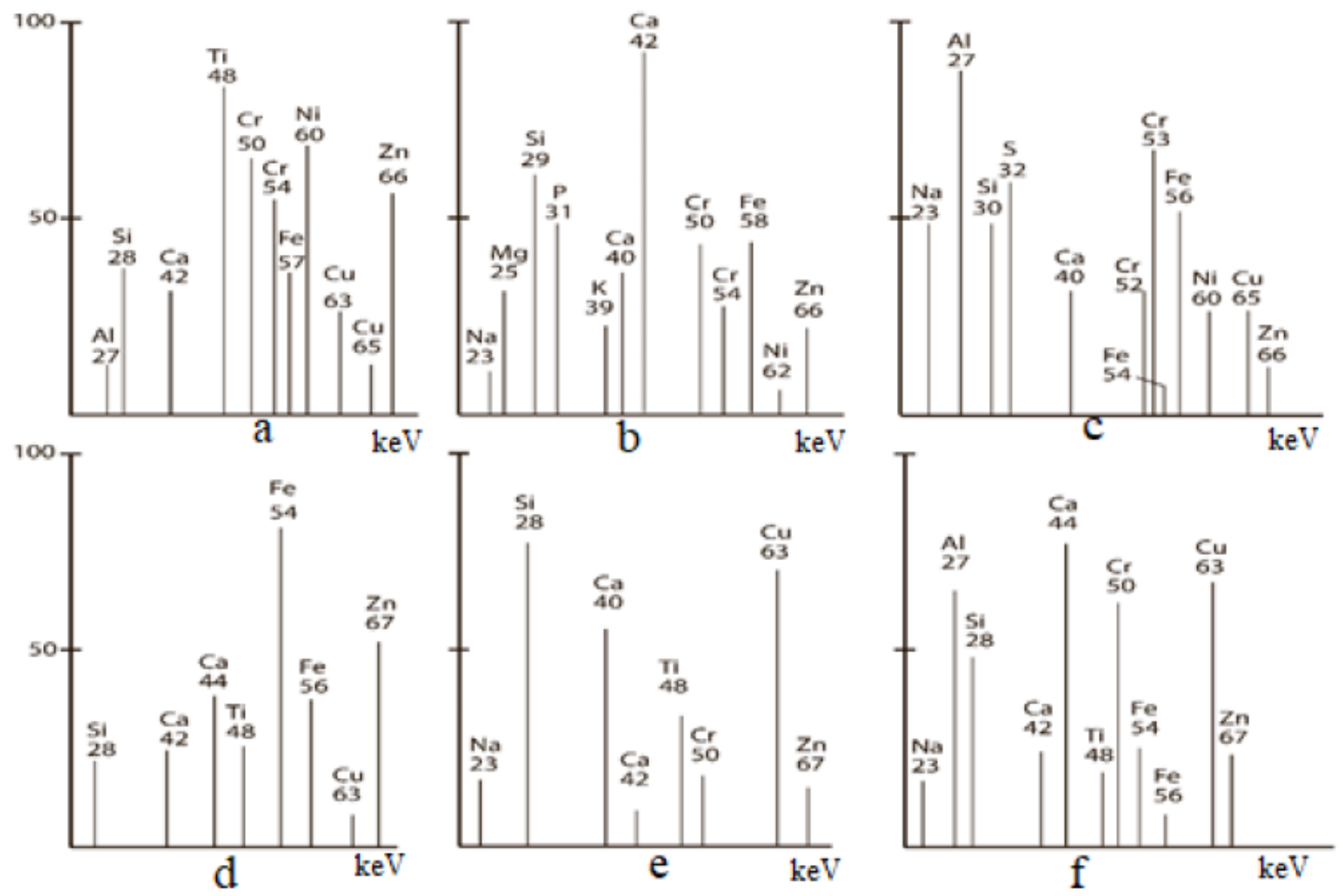

Figure 6

Isotopes' composites at different points of the composition 12 sample after hydration and curing for 90 days. 